Zeszyty Naukowe Szkoły Głównej Gospodarstwa Wiejskiego

Ekonomika i Organizacja Gospodarki Żywnościowej nr 111, 2015: 111-121

Jacek Maśniak

Katedra Ekonomii i Polityki Gospodarczej

Szkoła Główna Gospodarstwa Wiejskiego w Warszawie

\title{
Cykl koniunkturalny w rolnictwie z perspektywy austriackiej szkoły ekonomii
}

\section{Wstęp}

Rolnictwo, podobnie jak cała gospodarka narodowa, podlega cyklicznym wahaniom produkcji. W badaniach nad przyczynami cyklu koniunkturalnego coraz częściej zwraca się uwagę na silny związek koniunktury w rolnictwie z koniunkturą ogólnogospodarczą. Obserwacja ostatniego kryzysu z 2008 roku również wskazuje na silne zintegrowanie całego systemu gospodarczego. Co więcej, integracja ta jest daleko posunięta nie tylko w skali gospodarki narodowej, ale dotyczy całej gospodarki światowej. Tym samym porzucenie podejścia sektorowego w badaniach nad rzeczywistością gospodarczą na rzecz podejścia systemowego wydaje się szczególnie uzasadnione.

Główny nurt badań nad przyczynami i przebiegiem cykli koniunkturalnych nie przyniósł jak dotychczas zadowalających rezultatów. O małej wartości poznawczej tych badań może świadczyć zawodność polityki gospodarczej - nie przewidziano ostatniego kryzysu oraz nie podjęto skutecznych środków zapobiegawczych. W dyskusjach ekonomistów zauważamy ciagłe stawianie pytań o przyczyny kryzysu oraz wysuwane sa postulaty o weryfikacje dotychczasowego warsztatu badawczego i sięganie do alternatywnych szkół i kierunków badań w ekonomii. Znamienne pod tym względem jest wystąpienie Prezesa NBP Marka Belki [2013] na Kongresie Ekonomistów Polskich 28-29.11.2013 r., który stwierdził: „Ekonomia jako dyscyplina naukowa nie radzi sobie najlepiej z odpowiadaniem na pytania o przyczyny obserwowanych zjawisk. Metodyka badań ekonomicznych nakierowana jest przede wszystkim na poszukiwanie odpowiedzi na pytania o skutki różnych działań. (...) Kryzysy, szczególnie o takiej skali, jak wspomniany wcześniej wielki kryzys z lat 30., bądź ten, którego końca obecnie wypatrujemy, prowadzą do intensywnie zadawanych pytań „dlaczego”, głównie chyba z tego powodu, że pojawienie się takich zjawisk nie było oczekiwane (przynajmniej przez ekonomię głównego nurtu i opartą na niej politykę gospodarcza)". 
Jako alternatywne źródło wiedzy o rzeczywistości gospodarczej - spośród bardzo bogatego dorobku myśli ekonomicznej - można wskazać austriacką szkołę ekonomii. Szkoła ta wskazuje, że słabe rozpoznanie zarówno źródeł kryzysów, jak i mechanizmów ich rozprzestrzeniania się, wynika przede wszystkim $\mathrm{z}$ ignorowania roli praw własności w wyjaśnianiu rzeczywistości społeczno-gospodarczej oraz błędów w metodologii. Ekonomiści szkoły austriackiej twierdza, że prawo własności jest podstawowym instrumentem rozwiązywania konfliktów w sposób pokojowy. Dzięki internalizacji kosztów i korzyści ludzkich działań prowadzi do ograniczenia ryzykownych zachowań. Brak zastosowania teorii praw własności w stosunku do produkcji pieniądza nie pozwala na gruntowne wyjaśnienie zachowań kryzysogennych. Również empiryczne stanowisko metodologiczne, szeroko stosujące metody ekonometryczne, musi zawodzić. Prowadzi ono bowiem do przesadnego upraszczania rzeczywistości i poszukiwania związków przyczynowo-skutkowych w danych ilościowych. W odpowiedzi na te mankamenty przedstawiciele szkoły austriackiej proponują dynamiczne ujęcie procesów rozwojowych i zastosowanie podejścia aprioryczno-dedukcyjnego.

Celem artykułu jest przedstawienie zjawiska cykliczności w polskim rolnictwie z perspektywy austriackiej szkoły ekonomii. W pracy postawiono następujące cele szczegółowe:

- prezentacja austriackiej teorii cyklu koniunkturalnego (ATCK),

- opis cyklu koniunkturalnego w rolnictwie na tle zmian w całej gospodarce narodowej,

- przedstawienie mechanizmu prowadzącego do strukturalnego zróżnicowania cyklu koniunkturalnego w gospodarce narodowej i umiejscowienie rolnictwa w tym cyklu.

Na podstawie literatury omówiono główne twierdzenia wysuwane w ATCK. Również w oparciu o tę teorię została przedstawiona charakterystyka rolnictwa w odniesieniu do struktury produkcji, rozumianej jako stopień oddalenia produkcji od konsumenta, co jest zasadniczym czynnikiem różnicującym przebieg cyklu koniunkturalnego w poszczególnych sektorach gospodarki.

Do badań empirycznych zostały wykorzystane dane Głównego Urzędu Statystycznego dotyczace PKB, produkcji rolnej i przemysłowej w ujęciu realnym. Zmienność produkcji w czasie badana była za pomocą rocznych wskaźników wzrostu. Wzrost gospodarczy analizowano za pomocą rocznej dynamiki realnego PKB.

\section{System pieniężny i cykl koniunkturalny w ATCK}

Austriacką teorię cyklu koniunkturalnego zalicza się do teorii monetarnych. W teorii tej za główny impuls wywołujący okresowe wzrosty i spadki produkcji uważa się ekspansję kredytową banków połączoną ze wzrostem podaży pienią- 
dza. Natomiast centralną rolę w wyjaśnianiu mechanizmu powodującego wahania aktywności gospodarczej odgrywają preferencja czasowa oraz struktura produkcji i cen.

Struktura produkcji opisywana jest jako etapy produkcji od pierwotnych czynników produkcji (praca i zasoby naturalne) do gotowych dóbr konsumpcyjnych. W ten sposób dobra konsumpcyjne mogą być wytwarzane metodami, w których pierwotne czynniki produkcji przechodzą niewiele etapów produkcji i szybko osiągają postać dóbr konsumpcyjnych, albo przy użyciu metod okrężnych. Okrężne metody produkcji angażują większy zasób kapitału, wydłużają proces produkcji w czasie, ale pozwalają na wytworzenie większej masy dóbr konsumpcyjnych [Skousen 2007].

Struktura produkcji jest ściśle powiązana z preferencją czasową konsumentów. Wysoka preferencja czasowa oznacza, że konsumenci są nastawieni na konsumpcję dzisiejsza, niska zaś skłania ich do rezygnacji ze zwiększania konsumpcji dzisiejszej na rzecz przyszłej. W warunkach stałej podaży pieniądza zwiększenie akcji kredytowej banków możliwe jest tylko na skutek zwiększenia się oszczędności społeczeństwa. Jeżeli ludzie cenią bardziej teraźniejszą niż przyszłą konsumpcję, to zgromadzą niewielkie oszczędności, przez co rynkowa cena środków pożyczkowych staje się wysoka. Wysoka stopa procentowa powoduje, że tylko niewielka liczba inwestycji jest zyskowna, a struktura kapitałowa nie jest intensywnie rozbudowywana. Jeśli konsumenci obniżają swoje preferencje czasowe i zaczynają gromadzić oszczędności, to wzrost podaży wolnych środków pożyczkowych obniża rynkową stopę procentową, a niska stopa procentowa pobudza inwestycje. Jest to bodziec dla przedsiębiorców do zwiększenia inwestycji w sektorach dóbr kapitałowych. Po zrealizowaniu tych inwestycji struktura produkcji w gospodarce staje się bardziej kapitałochłonna i pozwala na produkcję większej ilości dóbr. Stopa procentowa, która równoważy dobrowolne oszczędności z inwestycjami, nazywana jest naturalną stopą procentową i jest ona integralnym elementem systemu cen rynkowych, które koordynują społeczną współpracę. Przy czym trzeba zauważyć, że w koordynowaniu decyzji długookresowych kluczową rolę odgrywa stopa procentowa kapitału pożyczkowego [Hayek 1967, Mises 2007, Rothbard 2007].

Cykl koniunkturalny w gospodarce powstaje w sytuacji, gdy ekspansja kredytu bankowego nie ma pokrycia w zwiększonych oszczędnościach społeczeństwa (rys. 1). Sytuacja taka ma miejsce we współczesnych systemach monetarnych, nazywanych przez austriacką szkołę ekonomii pieniądzem fiducjarnym. System taki opiera się na monopolu państwa na produkcję pieniądza i usankcjonowanej przez prawo rezerwie częściowej w bankowości. Bank centralny państwa ma wyłączność na emisję pieniądza gotówkowego (baza monetarna), z kolei banki komercyjne mają przywilej kreowania bezgotówkowego pieniądza kredytowe- 


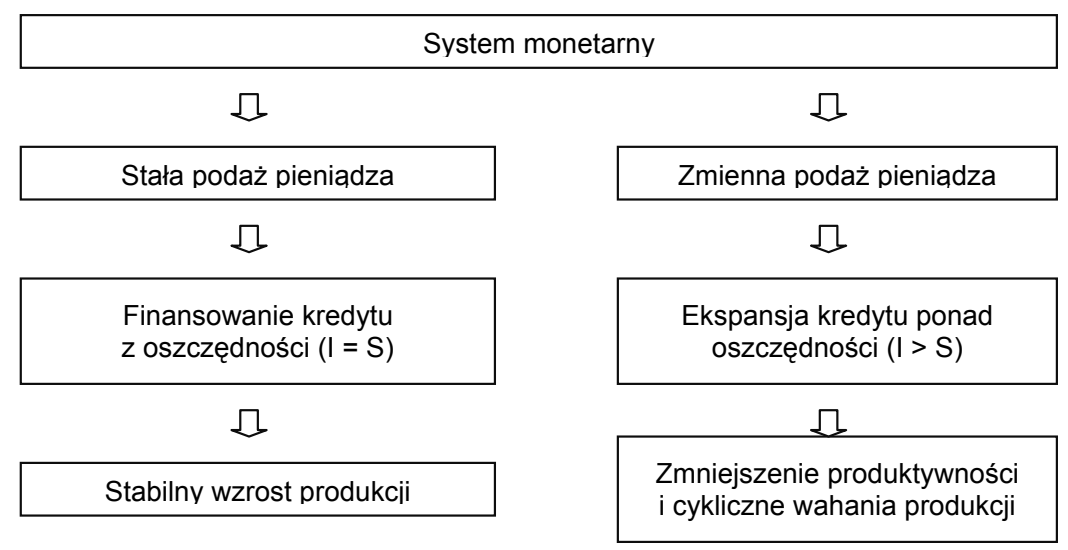

\section{Rysunek 1}

Wpływ systemu monetarnego na koniunkturę gospodarczą

Źródło: Opracowanie własne.

go, który nie ma pokrycia w oszczędnościach ludności. Banki komercyjne, będąc częścią kontrolowanego przez państwo systemu bankowego, są chronione przed utratą płynności i bankructwem poprzez rządowe gwarancje wypłaty depozytów, kredyty udzielane przez bank centralny oraz inne formy dofinansowania. Rozwiązania takie skutkują tym, że podaż pieniądza może szybko zmieniać się w czasie [Huerta de Soto 2009].

W okresie pobudzania koniunktury bank centralny prowadzi politykę łatwego pieniądza, czyli poprzez obniżanie stóp procentowych chce uruchomić wzrost akcji kredytowej banków komercyjnych. Pieniężna stopa procentowa spada poniżej naturalnej stopy procentowej, a na rynku pojawia się więcej wolnych środków pieniężnych dostępnych dla przedsiębiorców. Następuje szybki wzrost inwestycji finansowanych kredytami bankowymi. Kiedy kredytobiorcy wydają dodatkowe pieniądze, podnoszą ceny towarów, które kupują. Największy rozkwit przeżywają sektory produkujące dobra kapitałowe. Notują one ponadprzeciętne wyniki, a także rosną płace osób w nich zatrudnionych. W niektórych sektorach pojawiają się gwałtowne wzrosty cen, które z czasem przeradzają się w bańki spekulacyjne. W tym przypadku jednak ekspansji kredytu nie towarzyszy wzrost oszczędności (i odpowiedni spadek konsumpcji) w społeczeństwie. Preferencje konsumentów pozostają niezmienione i wydają oni swoje dochody zgodnie z dotychczasowymi preferencjami czasowymi. Dodatkowo zaniżone stopy procentowe zwiększają popyt na kredyty konsumpcyjne, przez co jeszcze zmniejsza się skłonność społeczeństwa do oszczędności. Utrzymywanie się obecnej konsumpcji na stałym poziomie nie pozwala na przesunięcie zasobów do nowych przedsięwzięć produkcyjnych. Wkrótce następuje wzrost cen dóbr konsumpcyjnych. Rosnące ceny czynników produkcji podnoszą koszty wytwarzania. Także zwięk- 
szone płace pracowników zatrudnionych w sektorach przeżywających boom są wydawane zgodnie z dotychczasową relacją konsumpcji i oszczędności. Okazuje się, że w gospodarce jest za mało zasobów, aby ukończyć wszystkie projekty inwestycyjne rozpoczęte dzięki ekspansji kredytowej. Dla przedsiębiorców i pożyczkodawców staje się jasne, że obserwowany rozkwit nie może być kontynuowany. Pojawiająca się inflacja cenowa zmusza bank centralny do podniesienia stóp procentowych, co definitywnie kończy fazę boomu. Podmioty gospodarcze mają coraz większe problemy ze spłacaniem kredytów i zaciąganiem nowych. $\mathrm{W}$ rezultacie podaż pieniądza zmniejsza się. W okresie recesji rośnie bezrobocie i następuje spadek wyceny dóbr kapitałowych. Jest to okres likwidowania nietrafionych inwestycji i realokacji zasobów do sektorów, w których mogą znaleźć produktywne zastosowanie. Jeżeli procesy te nie są zaburzone, przemieszczenie zasobów odbywa się stosunkowo szybko i gospodarka wraca do prawidłowego stanu [Huerta de Soto 2009].

Analiza struktury produkcji oraz cen w cyklu koniunkturalnym pozwala zaobserwować następującą prawidłowość: produkcja i ceny dóbr kapitałowych wykazują bardzo duże wahania - silnie wzrastają w fazie wzrostowej gospodarki, a następnie odnotowują wyraźne spadki w fazie recesji; rynki dóbr konsumpcyjnych są natomiast bardziej stabilne - produkcja i ceny nie podlegają tak silnym wahaniom. Nieliczne w tym zakresie badania empiryczne dla polskiej gospodarki potwierdzają tę prawidłowość. W fazie wzrostowej gospodarki wydłużała się struktura produkcji, a produkcja dóbr najbardziej odległych od konsumenta oraz dóbr trwałych wzrastała szybciej niż produkcja artykułów, które znajdują się w bliższej odległości od finalnego odbiorcy. Z kolei w fazach stagnacji produkcja ta spadała najszybciej. Artykuły spożywcze zachowywały się w sposób typowy dla dóbr konsumpcyjnych - produkcja i ceny były relatywnie stabilne [Jędruchniewicz 2012, 2013].

Inny wniosek wypływający z teorii cyklu koniunkturalnego to taki, że produkcja surowców, w tym również surowców żywnościowych dostarczanych przez rolnictwo, zalicza się do etapów produkcji odległych od konsumenta. W związku z tym w poszczególnych fazach cyklu koniunkturalnego produkcja ta będzie podlegać silniejszym wahaniom niż produkcja dóbr konsumpcyjnych.

\section{Rolnictwo w polskim cyklu koniunkturalnym}

Badanie koniunktury w rolnictwie na tle koniunktury gospodarczej w Polsce obejmuje lata 1999-2013. Jako miernik koniunktury została wykorzystana roczna dynamika realnego PKB. Metodą wykorzystaną do określania morfologii cyklu była analiza trendu zmian PKB. Wzrost gospodarczy w Polsce 


\section{6}

w tym okresie miał względnie stabilny przebieg, polegający na przyspieszeniu i osłabieniu tempa wzrostu realnego PKB. W tego rodzaju cyklu koniunkturalnym wyróżnić można jedynie fazę ożywienia oraz fazę stagnacji. Uwzględniając charakter zmian, które w pełni ujawniają się w dłuższych okresach, dążono do wyodrębnienia średnich faz cyklu koniunkturalnego obejmujących okresy 5-7-letnie. Takie podejście do problemu podyktowane jest również dostępnymi danymi, które prezentowane są w ujęciu rocznym, co uniemożliwia analizowanie zmian w krótkich odcinkach czasu. W ten sposób cykl koniunkturalny w Polsce został podzielony na trzy okresy. Wyodrębnione zostały dwie fazy stagnacji: 1999-2002 i 2009-2013 oraz jedna faza ożywienia 2003-2008.

W tabeli 1 przedstawiona została roczna dynamika PKB oraz produkcji rolniczej globalnej i końcowej na tle produkcji sprzedanej przemysłu. Produkcja przemysłowa obejmuje tylko główne jej składowe, tj. górnictwo i wydobywanie oraz przetwórstwo przemysłowe. $\mathrm{Z}$ przetwórstwa przemysłowego dodatkowo wyodrębniona została produkcja artykułów żywnościowych. Przyjęcie tej ostatniej zmiennej do badań jest szczególnie uzasadnione celem badań, zgodnie z którym przebieg cyklu koniunkturalnego uzależniony jest od stopnia oddalenia produkcji od konsumenta, zatem porównanie produkcji surowców żywnościowych i produkcji artykułów spożywczych będzie dawać szczególne podstawy do wnioskowania.

Do analizy przedstawionych danych wykorzystane zostały takie elementy statystyki opisowej, jak średni wskaźnik zmian i odchylenie standardowe. Na tle zmian w PKB produkcja globalna i końcowa rolnictwa wykazywała względnie dużą zmienność. Odchylenie standardowe wyniosło odpowiednio 4,28 i 4,19 pp. Większe wartości, bo 4,32 i 5,11 pp., osiaggnęły górnictwo i wydobywanie oraz przetwórstwo przemysłowe ogółem. W przypadku wyodrębnionej z produkcji przemysłowej grupy artykułów spożywczych odchylenie standardowe miało wartość najmniejszą i wyniosło 2,66 pp. Pozwala to wnioskować, że produkcja rolna wykazywała większą zmienność niż produkcja artykułów spożywczych, lecz nieco mniejszą zmienność niż górnictwo i produkcja przemysłowa ogółem. Tego rodzaju ujęcie wskazuje na podatność różnych rodzajów produkcji na wahania, jednak nie przedstawia przebiegu tej produkcji w różnych fazach cyklu koniunkturalnego.

Kierunki i siła zmian różnych rodzajów produkcji zostały również przeanalizowane $\mathrm{w}$ trzech wyodrębnionych fazach cyklu. W pierwszej badanej fazie stagnacji (1999-2002) produkcja globalna rolnictwa miała tendencję spadkowa, a średni roczny spadek wyniósł 1,7\% (rys. 2). W fazie wzrostu (2003-2008) produkcja ta odnotowała wzrost $\mathrm{w}$ średnim tempie $1,7 \%$. W następnej fazie stagnacji (2009-2013) wzrost ten był nieco słabszy i wyniósł 1,2\%. Produkcja końcowa rolnictwa była ogólnie wyższa, lecz wykazywała podobną tendencję, 
Tabela 1

Roczna dynamika PKB, produkcji rolnej i produkcji sprzedanej przemysłu w latach 1999_ $-2013$

\begin{tabular}{|c|c|c|c|c|c|c|}
\hline \multirow[b]{2}{*}{ Rok } & \multirow[b]{2}{*}{$\begin{array}{c}\text { Produkt } \\
\text { krajowy } \\
\text { brutto }\end{array}$} & \multirow[b]{2}{*}{$\begin{array}{c}\text { Produkcja } \\
\text { globalna } \\
\text { rolnictwa }\end{array}$} & \multirow[b]{2}{*}{$\begin{array}{l}\text { Produkcja } \\
\text { końcowa } \\
\text { rolnictwa }\end{array}$} & \multirow[b]{2}{*}{$\begin{array}{c}\text { Górnictwo } \\
\text { i wydoby- } \\
\text { wanie }\end{array}$} & \multicolumn{2}{|c|}{$\begin{array}{l}\text { Przetwórstwo } \\
\text { przemysłowe }\end{array}$} \\
\hline & & & & & razem & $\begin{array}{c}\text { w tym } \\
\text { produkcja } \\
\text { artykułów } \\
\text { spożyw- } \\
\text { czych }\end{array}$ \\
\hline 1999 & 104,50 & 94,80 & 96,00 & 97,40 & 103,60 & 100,60 \\
\hline 2000 & 104,30 & 94,40 & 96,80 & 97,40 & 107,30 & 101,30 \\
\hline 2001 & 101,20 & 105,80 & 108,60 & 95,10 & 99,40 & 102,60 \\
\hline 2002 & 101,40 & 98,10 & 100,10 & 97,90 & 101,20 & 99,70 \\
\hline 2003 & 103,90 & 99,20 & 102,50 & 96,80 & 110,20 & 107,90 \\
\hline 2004 & 105,30 & 107,50 & 108,00 & 101,90 & 113,60 & 105,00 \\
\hline 2005 & 103,60 & 95,70 & 97,90 & 100,00 & 103,90 & 107,10 \\
\hline 2006 & 106,20 & 98,80 & 100,00 & 97,40 & 112,80 & 106,20 \\
\hline 2007 & 106,80 & 105,90 & 105,60 & 100,50 & 110,60 & 107,40 \\
\hline 2008 & 105,10 & 103,20 & 103,60 & 103,30 & 104,00 & 100,60 \\
\hline 2009 & 101,60 & 102,40 & 103,00 & 87,20 & 97,00 & 105,70 \\
\hline 2010 & 103,90 & 97,30 & 97,30 & 98,80 & 109,90 & 104,60 \\
\hline 2011 & 104,50 & 102,20 & 103,60 & 104,50 & 108,70 & 104,10 \\
\hline 2012 & 102,00 & 99,10 & 99,00 & 95,00 & 101,20 & 104,10 \\
\hline 2013 & 101,60 & 105,10 & 107,30 & 103,60 & 102,20 & 102,40 \\
\hline średnia & 103,70 & 100,60 & 102,00 & 98,50 & 105,70 & 104,00 \\
\hline $\begin{array}{l}\text { Odchylenie } \\
\text { standar- } \\
\text { dowe }^{*}\end{array}$ & 1,80 & 4,28 & 4,19 & 4,32 & 5,11 & 2,66 \\
\hline
\end{tabular}

*Obliczone według wzoru: $\sqrt{\frac{\sum(x-\bar{x})^{2}}{(n-1)}}$, gdzie: $\mathrm{x}$ - średnia arytmetyczna, $\mathrm{n}$ - wielkość próby. Źródło: Rocznik statystyczny RP 2000-2014, GUS, Warszawa; obliczenia własne.

czyli tempo wzrostu było słabsze w fazach stagnacji $(0,4 \%$ i 2,0\%) i wyższe w fazie wzrostu $(2,9 \%)$. W pozostałych grupach produkcji można było zaobserwować podobną prawidłowość. Tempo wzrostu produkcji wyraźnie słabło w fazach stagnacji i zwiększało się w fazie ożywienia, przy czym największe wahania dotyczyły produkcji przemysłowej ogółem, gdzie produkcja rosła w tempie 2,9 i 3,8\% w fazach stagnacji oraz 9,2\% w fazie wzrostu. Produkcja artykułów spożywczych wykazywała ogólnie słabsze tempo wzrostu, tj. 1,1 i 4,2\% w fazach stagnacji oraz 5,7\% w fazie wzrostu. Górnictwo odznaczało się natomiast ogólną tendencją spadkową - produkcja spadała $\mathrm{w}$ tempie $2,2-3 \% \mathrm{w}$ fazach stagnacji i stabilizowała się w fazie ożywienia. 
๑faza stagnacji 1999-2002 ๑faza ożywienia 2003-2008 @faza stagnacji 2009-2013

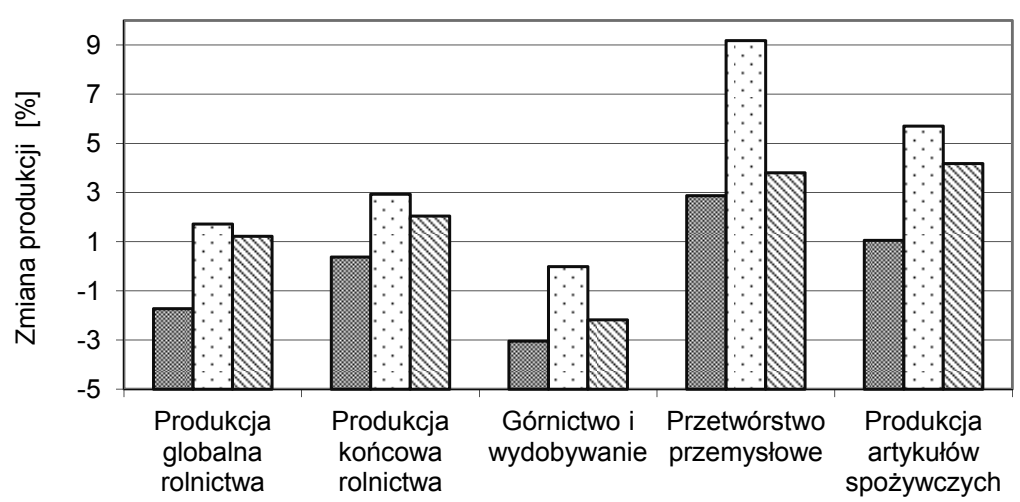

\section{Rysunek 2}

Średnie zmiany produkcji w poszczególnych fazach cyklu koniunkturalnego

Źródło: Obliczenia własne na podstawie Rocznik Statystyczny RP 2000-2013, GUS, Warszawa.

Obserwując zależność między produkcją rolną i produkcją przemysłową artykułów trzeba stwierdzić, że produkcja przemysłowa odznaczała się ogólnie większymi wahaniami niż produkcja rolna. Jednak wahania produkcji rolnej były większe niż w grupie artykułów żywnościowych. W ten sposób potwierdziła się ogólna prawidłowość, że rolnictwo, jako sektor surowcowy, stanowi etap produkcji bardziej oddalony od finalnego odbiorcy niż produkcja artykułów spożywczych, przez co podlega relatywnie większym wahaniom. Prawidłowość ta ujawniła się również przy porównaniu rolnictwa z innym sektorem surowcowym, takim jak górnictwo i wydobywanie. Sektor ten odznacza się większym oddaleniem od konsumenta pod względem liczby etapów produkcji niż rolnictwo i jednocześnie był bardziej podatny na wahania koniunkturalne. Stąd nasuwa się wniosek, że im większa liczba etapów produkcji oddziela dany sektor od konsumenta, tym większa podatność na okresowe wzrosty i spadki aktywności gospodarczej wywołane ekspansją pieniężną systemu bankowego. Jednocześnie trzeba stwierdzić, że produkcja rolna stanowi bezpośredni surowiec do produkcji żywności, co stanowi czynnik stabilizujący produkcję tego sektora.

Badania nad przebiegiem cyklu koniunkturalnego w sektorze rolno-żywnościowym prowadzono również w zakresie cen [Maśniak 2013]. Wyniki badań obejmujących lata 1998-2012 wskazują, że w poszczególnych fazach cyklu koniunkturalnego ceny ziemi kształtowały się w sposób typowy dla dóbr inwestycyjnych. Ceny ziemi podległy silniejszym wahaniom niż ceny dóbr konsumpcyjnych. Podobnie silne wahania dotyczyły towarowej produkcji rolniczej i nakładów inwestycyjnych w gospodarstwach indywidualnych. 
Należy zauważyć, że obserwowany w praktyce słabszy stopień zbieżności zmian $\mathrm{w}$ produkcji rolnej $\mathrm{z}$ teoretycznym modelem cyklu koniunkturalnego, ewentualnie odstępstwa od modelu, mogą wynikać z ograniczonej dostępności danych empirycznych. Niezależnie od powyższego trzeba też mieć na uwadze, że dane empiryczne obarczone są pewną ,niedoskonałością" związaną z tym, że są wynikiem działania wielu czynników. Dotyczy to zwłaszcza produkcji rolniczej, która jest silnie uzależniona od różnych czynników pozarynkowych, np. warunki atmosferyczne, sezonowość produkcji oraz silne uzależnienie sytuacji dochodowo-produkcyjnej rolników od polityki państwa, w tym od poziomu i sposobu subwencjonowania, regulowania rynków, kształtowania warunków handlu zagranicznego.

\section{Podsumowanie i wnioski}

Rolnictwo jest elementem systemu gospodarczego i podlega takim samym wahaniom cyklicznym w zakresie produkcji i cen jak cała gospodarka narodowa. Teoria cyklu koniunkturalnego według austriackiej szkoły ekonomii twierdzi, że główną przyczyną niestabilności gospodarczych, przejawiających się cyklicznymi wzrostami i spadkami produkcji, jest ekspansywna polityka pieniężna. Prowadzi ona do wydłużania struktury produkcji w fazie wzrostowej, gdzie największy rozwój przeżywają sektory czasowo najdalej odsunięte od konsumenta. Stąd największe nasilenie procesu inwestycyjnego występuje w sektorach wytwarzających dobra kapitałowe i surowce, służące do rozbudowy możliwości produkcyjnych. Jednak w fazie recesji sektory te notują również największe spadki. W świetle tej teorii rolnictwo, jako sektor surowcowy, jest względnie podatne na wahania cykliczne produkcji.

Badania przeprowadzone dla polskiej gospodarki w latach 1999-2013 wykazały, że w fazach stagnacji (1999-2002 i 2009-2013) produkcja globalna i końcowa rolnictwa notowały słabe tempo wzrostu, ewentualnie spadek. W fazie ożywienia (2003-2008) tempo wzrostu było wyższe. W przypadku produkcji przemysłowej ogółem można było zaobserwować podobną prawidłowość, lecz wahania produkcji były wyraźnie większe. Z kolei górnictwo odznaczało się ogólną tendencją spadkową - produkcja wyraźnie spadała w fazach stagnacji i stabilizowała się w fazie ożywienia.

Za czynnik stabilizujący produkcję rolną można uznać to, że w większości surowce rolne służą bezpośrednio do wytwarzania żywności, czyli dobra konsumpcyjnego o względnie stabilnym popycie. Przeprowadzona analiza porównawcza tych dwóch rodzajów produkcji wskazuje, że wahania produkcji rolnej były większe niż w grupie artykułów żywnościowych. 


\section{Literatura}

BARCZYK R., KĄSEK L., LUBIŃSKI M., MARCZEWSKI K. 2006: Nowe oblicza cyklu koniunkturalnego, PWE, Warszawa.

BELKA M. 2013: Dlaczego tylko odkrywać? Lekcje z obecnego kryzysu dla ekonomii i polityki gospodarczej, Bezpieczny Bank, nr 4(53), s. 7-18.

HAYEK F.A. 1967: Prices and Production, Augustus M. Kelly Publishers, New York.

HUERTA de SOTO J. 2009: Pieniqdz, kredyt bankowy i cykle koniunkturalne, Instytut Ludwiga von Misesa, Warszawa.

JĘDRUCHNIEWICZ A. 2012: Produkcja we wzrostowej fazie cyklu koniunkturalnego w Polsce, Gospodarka Narodowa, R. 23, nr 10, s. 73-95.

JĘDRUCHNIEWICZ A. 2013: Produkcja w spadkowej fazie cyklu koniunkturalnego $w$ Polsce, Ruch Prawniczy, Ekonomiczny i Socjologiczny, R. 75, z. 1, s. 155-174.

Kwartalne wskaźniki makroekonomiczne, http://stat.gov.pl/wskazniki-makroekonomiczne (data dostępu: 20.10.2014).

MISES L. 2007: Ludzkie działanie. Traktat o ekonomii, Instytut Ludwiga von Misesa, Warszawa.

Rocznik Statystyczny Rzeczypospolitej Polskiej 2000-2013, GUS, Warszawa.

ROTHBARD M.N. 2007: Ekonomia wolnego rynku, t. II i III, Fijor Publishing, Chicago.

SKOUSEN M. 2007: The Structure of Production, NYU Press, New York.

\section{Abstrakt}

Celem artykułu jest przedstawienie zjawiska cykliczności w polskim rolnictwie z perspektywy austriackiej szkoły ekonomii. Teoria cyklu koniunkturalnego według austriackiej szkoły ekonomii twierdzi, że główną przyczyną cyklu koniunkturalnego jest ekspansywna polityka pieniężna. Prowadzi ona do wydłużania struktury produkcji w fazie wzrostowej, gdzie największy rozwój przeżywają sektory czasowo najdalej odsunięte od konsumenta. Jednak w fazie recesji sektory te notują również największe spadki. W świetle tej teorii rolnictwo, jako sektor surowcowy, jest względnie podatne na wahania cykliczne produkcji. Badania przeprowadzone dla polskiej gospodarki w latach 1999-2013 wykazały, że wahania cykliczne produkcji globalnej i końcowej rolnictwa były mniejsze niż artykułów żywnościowych, lecz mniejsze niż produkcji przemysłowej ogółem.

Słowa kluczowe: austriacka szkoła ekonomii, cykl koniunkturalny, struktura produkcji 


\section{Business cycle in agriculture from the Austrian economics perspective}

\section{Abstract}

The aim of the article is to present the business cycle in Polish agriculture from the Austrian school of economics perspective. According to the Austrian business cycle theory, the main cause of business cycle is an expansionary monetary policy. It leads to lengthening the production structure in the growth phase. The largest growth is observed in sectors situated far away from the consumer. However, in the recession phase these sectors face the biggest downswings. The agriculture is relatively prone to fluctuations of production. A study carried out for the Polish economy in years 1999-2013 showed that the fluctuations of global and final agriculture output was larger than the food production, but smaller than the industry production.

Key words: Austrian school of economics, business cycle, production structure 
